\title{
Terorisme, Komodifikasi Rasa Takut dalam Infotainment: Melihat Kasus Bom Sarinah dengan Pandangan Ekonomi Politik Media Massa
}

\author{
Wininda Qusnul Khotimah ${ }^{1 *}$ \\ ${ }^{1}$ Prodi Ilmu Komunikasi, FISIP UHAMKA, Jl. Limau II, Kebayoran Baru, Jakarta Selatan, Indonesia, 12130 \\ * Email Korespondensi: winyninda@uhamka.ac.id
}

Kata kunci:

Isi

Infotainment

Komodifikasi

Teroris

Keyword:

Content

Commodification

Infotainment

Terrorism

\section{A B S T R A K}

Fokus penelitian ini adalah komodifikasi terorisme di media massa. Peneliti menggunakan pendekatan kualitatif, deskriptif. Teknik pengumpulan data dilakukan melalui kajian teks dan studi pustaka. Peneliti melihat bahwa media massa tidak hanya menjadikan terorisme sebagai topik utama dalam berita konvensional. Munculnya infotainment menjadikan informasi tentang terorisme sebagai suguhan yang menghibur, bahkan peristiwa yang menegangkan menjadi tontonan yang menarik. Melalui infotainment, kasus teror pemboman Sarinah dikomodifikasi sebagai informasi yang menjual keharuan dan ketakutan menjadi tontonan yang menyenangkan dan menghibur. Dengan demikian tontonan ini diharapkan dapat meningkatkan rating TV (baca: menghasilkan laba yang besar). Hasil penelitian ini menunjukkan bahwa infotainment dapat membuat kasus terorisme dikaitkan dengan selebritas. Kontennya juga tidak berupa ulasan jurnalisme yang mendalam, karena informasinya hanya berkisar di sekitar orang-orang terdekat selebritas dan satu atau dua ahli yang mengomentari kasus pemboman Sarinah. Hal ini menjadi nilai baru dalam menyampaikan berita terorisme.

\section{A B S T R A C T}

The focus of the study is the commodification of terrorism in the mass media. Through qualitative descriptive studies, and data collection through text studies and literature studies. In this research, the researcher sees that the media does not only make terrorism the main topic in traditional news. The emergence of infotainment has made information about terrorism an entertaining treat, even when the case should have been a tense case if published in traditional news. Through infotainment, the content of the Sarinah bombing terror case is commodified into information that sells blue emotions, and turns fear into a fun spectacle by turning it into more interesting and entertaining content, which is expected to increase TV ratings in the sense that it will generate profitable profits. great for the media through terrorism cases. The results of this study indicate that infotainment, terrorism cases are also associated with celebrities and the content does not carry deep journalism because the expansion of information only revolves around people around celebrities or one or two experts who also commented on the Sarinah bombing case, this makes a new value. in delivering terrorism news.

\section{PENDAHULUAN}

Dalam masa teknologi informasi, media memiliki peranan untuk menyebarkan berbagai informasi, terutama yang berkaitan dengan masalah publik seperti bencana alam, terorisme, isu politik, isu sosial dan budaya, isu ekonomi, dan lain sebagainya. Bagi media, penyediaan informasi ini berhubungan langsung dengan tingkat pendapatan korporasi media. Jika informasi yang disiarkan menarik minat banyak penonton, rating media akan meningkat dan profit yang dihasilkan juga bertambah. Oleh karenanya, media tidak sembarangan dalam menampilkan berita. Hanya isu-isu tertentu yang dianggap dapat menarik perhatian penontonlah yang ditampilkan. Isu tertentu ini, salah satu yang paling bisa menarik perhatian, adalah isu terorisme. Terorisme sebagai breaking news yang sempurna terlihat dari dihentikannya semua program acara televisi demi tayangan aksi terorisme yang mungkin saja lokasinya jauh dari penonton. Komoditas pertama dari sebuah media massa yang paling pertama adalah content media. Proses komodifikasi ini dimulai ketika pelaku media mengubah pesan melalui teknologi yang ada menuju sistem interpretasi yang penuh makna hingga menjadi pesan yang marketable, tidak terkecuali kasus terorisme.

Aksi terorisme yang terjadi di daerah Thamrin, Jakarta 14 Januari lalu mengingatkan 
kembali bahwa Indonesia masih belum terbebas dari isu terorisme. Bom Bali $(2002,2005)$ dan Bom Marriott (2009) misalnya, memakan banyak korban jiwa dan mendapatkan perhatian nasional dan internasional yang luas. Perbedaan terletak pada pelaku teror. Jika dulu Al-Qaida dan Jamaah Islamiyah ditunjuk sebagai biang kerok, kini Islamic State atau IS ditunjuk sebagai pihak yang paling bertanggungjawab. Tidak jauh berbeda sebenarnya, keduanya tetap menggunakan kelompok Islam (isu agama) sebagai momok yang mengancam keamanan negara. Di Indonesia misalnya, pernah ada kasus Tv One yang menayangkan "penyerbuan Temanggung" selama hampir 24 jam (2009), atau ANTV yang pernah menayangkan momen tembak-menembak antara polisi dengan pasukan teroris yang dipimpin Azahari di Malang (2005). Hal tersebut terjadi pada konten berita (tradisional) yang ada pada beberapa stasiun televisi. Hal serupa ternyata dilakukan oleh program acara infotainment di beberapa stasiun televisi tersebut. Teror bom Sarinah menjadi topik yang hangat dalam beberapa hari acara yang seharusnya membahas informasi mengenai kehidupan selebriti, masakan, hobi, dan keunikan lain yang mengandung unsur hiburan tanpa memuat unsur berita. Praktiknya, ternyata kasus teror tersebut diproduksi oleh media menjadi informasi yang menjual nilai kesenangan dan hiburan dalam menontonnya. Beberapa tema dalam infotaiment menjadi sesuatu yang sangat berbeda dengan yang disajikan oleh berita pada umumnya. Infotainment yang seharusnya menyuguhkan gosip seputar selebritis dan lifestyle orang-orang terkenal, ketika dihadapkan dengan kasus terorisme-pun akan menjadikannya olahan informasi yang tidak kalah menjual dengan berita yang ada pada umumnya.

Dari latar belakang di atas, maka hal menarik yang mendasari penulisan ini adalah:Kasus Bom Sarinah di daerah Thamrin Jakarta yang menjadi headline news di seluruh media massa Indonesia beberapa waktu lalu, juga menjadi informasi utama program acara infotainment. Kemudian, tulisan ini akan membahas bagaimana :

1. Simbiosis yang terjadi antara terorisme dan media massa

2. Infotaiment di Media Indonesia

3. Komodifikasi Rasa takut sebagai tontonan dalam
Infotainment

(komodifikasi

konten)

\section{METODE PENELITIAN}

Pada penelitian ini metode kualitatif deskriptif dipilih sebagai sarana untuk menggambarkan fenomeman terorismetainment di Indonesia. Studi deskriptif dengan pendekatan kualitatif menurut Moleong (2001) merupakan metode yang digunakan untuk menemukan fakta dan melakukan interpretasi, menggambarkan secara akurat sifat-sifat dari beberapa fenomena.

\section{HASIL DAN PEMBAHASAN}

Pemanfaatan kasus bom Sarinah tidak hanya dilakukan oleh media berita di Indonesia. Tayangan-tayangan Informasi Selebriti atau yang disebut dengan Infotainment juga tidak kalah dalam memberitakan kasus tersebut. Tidak heran kadang muncul pertanyaan, sebenarnya khalayak sedang menyaksikan berita terorisme ataukah infotainment (gossip) tentang terorisme. Beberapa informasi mengenai terorisme disajikan secara ringan dan dijadikan komoditas tayangan televisi untuk menaikkan rating. Beberapa tayangan tersebut adalah :

Tabel 1

Teror Bom Sarinah dalam bingkai Infotainment

\begin{tabular}{|l|l|}
\hline \multicolumn{1}{|c|}{$\begin{array}{c}\text { Program } \\
\text { Tayangan } \\
\text { Infotaiment }\end{array}$} & \multicolumn{1}{|c|}{ Judul Tayangan } \\
\hline $\begin{array}{l}\text { Insert } \\
\text { TransTv }\end{array}$ & $\begin{array}{l}\text { Ada Polisi Ganteng di } \\
\text { Balik Bom Thamrin (16 } \\
\text { Januari 2016) } \\
\text { Tanggapan Para Selebriti } \\
\text { mengenai Teror di } \\
\text { Sarinah (21 Januari } \\
\text { 2016) }\end{array}$ \\
\hline $\begin{array}{l}\text { Rumpi No } \\
\text { Secret } \\
\text { TransTv }\end{array}$ & $\begin{array}{l}\text { Kondisi Thamrin Pasca } \\
\text { Bom Sarinah (14 Januari }\end{array}$ \\
\hline $\begin{array}{l}\text { Hitam Putih } \\
\text { Trans7 }\end{array}$ & $\begin{array}{l}\text { Kisah Unik di balik Bom } \\
\text { Thamrin }\end{array}$ \\
\hline $\begin{array}{l}\text { KISS } \\
\text { Indosiar }\end{array}$ & $\begin{array}{l}\text { Tragedi Bom Thamrin } \\
\text { (15 Januari 2016) } \\
\text { Teror Bom di Sarinah- } \\
\text { Hot Issue (16 Januari }\end{array}$ \\
\hline
\end{tabular}




\begin{tabular}{|c|c|}
\hline & 2016) \\
\hline Silet RCTI & $\begin{array}{l}\text { - } \text { Teka - teki Pelaku Teror } \\
\text { Bom Sarinah (15 Januari } \\
\text { 2016) } \\
\text { Polisi Tampan dan } \\
\text { Modis di Tragedi Sarinah } \\
\text { jadi Perbincangan (15 } \\
\text { Januari) }\end{array}$ \\
\hline $\begin{array}{l}\text { Dahsyat } \\
\text { RCTI }\end{array}$ & 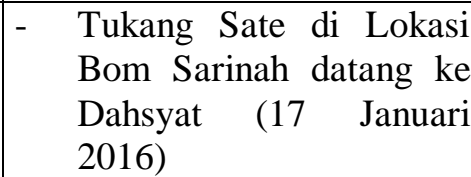 \\
\hline $\begin{array}{ll}\text { Hot } & \text { Shot } \\
\text { SCTV } & \end{array}$ & 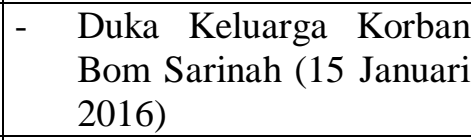 \\
\hline $\begin{array}{l}\text { Selebrita } \\
\text { Pagi Trans7 }\end{array}$ & 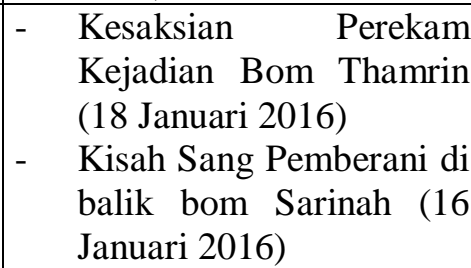 \\
\hline
\end{tabular}

Tabel di atas merupakan contoh tayangan infotaiment kasus pengeboman Sarinah Thamrin jika dikelompokkan berdasarkan perusahaan stasiun televisinya, maka Transcorp yang menaungi stasiun Trans Tv dan Trans 7 adalah yang yang paling banyak mengemas kasus bom Sarinah menjadi informasi utama dari infotainment. Infotaiment seakan-akan berperan menjadi bagian dari berita.

Dengan memasukkan kasus bom Sarinah sebagai topik utama, program acara infotainment tersebut merasa memiliki tanggung jawab yang sama dengan berita tradisional yang ada di televisi dengan mencoba memasukkan unsur dari nilai berita yang ada. Judul yang digunakan dalam peliputan kasus pengeboman tersebut tak kelah menarik perhatian masyarakat awam. Sebut saja beberapa judul yang menjual kesedihan yang dijadikan tontonan seperti, "Duka Keluarga Korban Bom Sarinah" yang ditayangkan oleh infotainment Hot Shot SCTV.

Beberapa konflik, seperti kasus pengeboman di Sarinah tidak jarang akan memunculkan serangkaian konten kesedihan yang akan dikomodifikasikan menjadi tontonan yang mengharu biru dan dikonsumsi audiensnya. Kemudian, beberapa judul lain tidak kalah memunculkan kehebohan, skandal dan sensasi khas infotainment seperti "Ada Polisi Ganteng di Balik Bom Thamrin", "Tukang Sate di Lokasi Bom Sarinah datang ke Dahsyat", "Polisi Tampan dan Modis di Tragedi Sarinah jadi Perbincangan". Kasus pengeboman Sarinah yang menelan korban dikemas secara berbeda oleh infotainment, kasus tersebut tidak lagi menyuguhkan sisi isu keamanan yang perlu diperhatikan oleh Negara, tetapi bagaimana kasus tersebut berubah dari isu yang menegangkan menjadi isu ringan yang menghibur dan menjadi tontonan yang menarik. Sebut saja salah satu judul dari tayangan Insert Tv "Tanggapan Para Selebriti mengenai Teror di Sarinah", kasus terorisme ditunjkkan sebagai kasus yang akan laris dijual dari sisi manapun, tak terkecuali hanya berupa tanggapan dari para selebritis yang merasa iba peduli dengan kasus tersebut. Media Media massa memosisikan informasi tidak lebih dari sebuah transaksi yang ditujukan untuk memenuhi kebutuhan konsumen dipasar informasi (Adam, 2011:4).

Melihat berbagai kejadian tersebut, sulit untuk menyangkal bahwa terdapat simbiosis mengkhawatirkan antara media dan terorisme. Media mendapatkan tontonan besar dan menarik, serta pihak teroris mendapatkan "juru bicara" untuk menyampaikan pesan-pesan mereka. Cukup mengkhawatirkan jika teroris semakin memahami dan memanfaatkan cara kerja media untuk kepentingan mereka. Satu temuan menarik, di antara berbagai jenis terorisme, serangan bunuh diri merupakan salah satu yang paling mudah mendapatkan perhatian media. Hal ini bisa jadi terkait dengan nilai kenekatan dan keanehan serangan bunuh diri, mengingat absurditas adalah salah satu komponen tontonan yang menarik dan bernilai tinggi untuk diangkat media. Wajar jika serangan bunuh diri menjadi salah satu metode favorit yang dipilih teroris.

Dari kasus ini, bisa dilihat seberapa jauh timbal balik keuntungan yang akan didapatkan antara media dan terorisme. Media yang memberitakan kasus penangkapan teroris secara eksklusif akan menjadi tontonan yang menarik bagi masyarakat. Masyarakat mencoba menerimanya dengan rasa ketidak amanan yang menyenangkan. Tontonan yang mengancam kehidupan mereka tetapi mengasyikkan, atau tontonan yang sekiranya mengasyikkan bagi mereka dan memunculkan ideologi betapa berbahayanya aksi terorisme. Berita-berita di televisi menyajikan terorisme 
sebagai bahan konflik yang menarik untuk diolah, berbeda dengan kasus kelaparan atau kemiskinan yang tidak menunjukkan unsur violence di dalamnya. Kemudian, dari peran media yang memunculkan pemberitaan mengenai terorisme, maka munculah pemerintah sebagai pihak penenang yang mencoba melegitimasi keberadaan teroris. Pihak teroris juga akan semakin merasa kemenangan berada di tangan nya, ketika pemberitaan di berbagai media tertuju kepada aksinya.

Menurut McQuail, sebagaimana media lain, televisi memiliki empat fungsi utama, yaitu: pendidikan, sosial kontrol, informasi, dan hiburan (McQuail, 2005). Akan tetapi, dalam bukunya Amusing Ourselves to Death (1985), Neil Postman menyebutkan bahwa bagimasyarakat modern, televisi hanya melayani fungsi hiburan secara dominan dan cenderungmengabaikan fungsi-fungsi lainnya. Jika suatu tayangan televisi pun memiliki fungsi sosial, pendidikan, atau informasional, acara yang ditayangkan di televisi itu pun pasti disisipi oleh unsur-unsur yang menghibur. Argumen Postman ini beranjak dari logika industrialisasi yang menitikberatkan pada komodifikasi yaitu yang terpenting dari suatu komoditas ialah seberapa besar produk tersebut disukai (nilai tukar), bukan seberapa besar manfaat produk tersebut (nilai guna). Oleh karena itulah, hiburan menjadi alat utama untuk menarik publik.

Menurut Postman (1985), hiburan merupakan supra-ideologi dari seluruh diskursus publik ditelevisi. Karenanya, unsur hiburan yang menyisipi segala tayangan televisi tersebut mempengaruhi hampir seluruh aspek kehidupan manusia, sebagai konsumen tayangan televisi tersebut. Tayangan televisi yang dipenuhi segala unsur hiburan tersebu tmempengaruhi cara pandang, cara berpikir, cara bicara, hingga cara orang memilih sikap. Dalam format talkshow, hiburan merupakan sesuatu yang dikultuskan karena menyediakan ruang bagi audiens untuk melepaskan diri dari realita yang membuat mereka tertekan dan kondisi kehidupan sehari-hari yang tidak menyenangkan. Tidak terkecuali pada kasus pengeboman Sarinah tersebut, beberapa narasumber dan topik Polisi tampan menjadi bentuk pengalihan media untuk merubah kasus terorisme menjadi realitas yang sedikit terlupakan.

\section{a.) Komodifikasi Rasa Takut Sebagai Tontonan dalam Infotaiment}

Dalam tesis industri budaya Adorno, disebutkan bahwa sebagai salah satu produk budaya,media menjadi suatu objek yang diperjualbelikan atau dianggap sebagai komoditas. Komodifikasi media tersebut diatur dalam prinsip nilai tukar, bukan nilai gunanya, sehingga apa yang paling bernilai untuk ditampilkan di media adalah yang paling mampu menarik masyarakat, bukan berdasarkan muatan apa yang paling berguna (Adorno, 1954). SedangkanVincent Mosco, dalam bukunya The Political Economy of Communication (2009:132), mendefinisikan komodifikasi sebagai proses mengubah nilai pada suatu produk yang tadinya hanya memiliki nilai guna kemudian menjadi nilai tukar (nilai jual) dimana nilai kebutuhan atas produk ini ditentukan lewat harga yang sudah dirancang oleh produsen. Begitupula halnya dengan tayangan infotainment yang menjadi salah satu komoditas media.

Sebagai dampak industrialisasi media, infotainment juga diposisikan sebagai salah satu sumber pendapatan yang paling menghasilkan nilai tukar. Infotainment berkembang menjadi komoditas media yang menjanjikan karena yang terjadi bukan hanya komodifikasi untuk mendapatkan nilai tukar yang bertambah (surplus value), tapi juga karena pesan yang disampaikan mengandung simbol dan citra yang bisa dimanfaatkan untuk mengkonstruksi realitas yang diterima di benak penonton sebagai penerima pesan. Masalah makna atau nilai guna yang dimuat dalam infotainment tidak lagi menjadi hal yang penting karena dasa rlogika yang digunakan ialah bagaimana media bias menayangkan acara yang paling menghibur, paling menarik animo masyarakat, bukan apa yang mendidik masyarakat. Dalam industri komunikasi sendiri, dikenal tiga jenis komodifikasi, yaitu komodifikasi konten, komodifikasi audiens, dan komodifikasi buruh (Mosco, 2009) dari ketiga pintu masuk komodifikasi tersebut, kasus mengenai teror bom Sarinah lebih mengarah kepada komodifikassi konten yang dimuat dalam berbagai infotaiment di beberapa stasiun televisi.

\section{b.) Komodifikasi Konten Media}


Menurut Mosco (2009), komodifikasi konten merujuk pada proses transformasi pesan dari hanya sekedar informasi menjadi sistem pemikiran penuhmakna dalam bentuk produk yang dapat dipasarkan. Artinya, terjadi pengolahan konten media agar disukai oleh publik meski pada dasarnya konten tersebut tidak dibutuhkan oleh publik. Dalam tayangan infotainment, komodifikasi konten dilakukan dengan cara menciptakan dramatisasi informasi mengenai selebritis sehingga informasi yang sebenarnya tidak memiliki signifikansi bagi masyarakat dapat menarik minat publik untuk menyaksikan karena timbul rasa ingin tahu terhadap segala informasi mengenai selebritis tersebut, terutama ketika sifatnya sensasional dan terus-menerus digali dan ditayangkan. Seperti kasus pengeboman di Sarinah, yang mana sebenarnya kasus tersebut merupakan kasus yang memuat banyak nilai berita.

Namun dalam praktik komodifikasi konten, nilai berita tersebut dirubah menjadi acara hiburan yang memuat informasi yang sebenarnya tidak penting untuk diketahui oleh khalayak, namun karena kepentingan bisnis yang akan menaikan rating, maka kasus terorisme-pun bisa menjadi sesuatu yang menguntungkan bagi media melalui program infotainmentnya. Sebut saja beberapa narasumber dan judul-judul yang digunakan dalam infotainment tersebut seperti, "Tukang Sate di Lokasi Bom Sarinah datang ke Dahsyat", "Ada Polisi Ganteng di Balik Bom Thamrin", "Tanggapan Para Selebriti mengenai Teror di Sarinah", segala informasi tersebut sebenarnya tak berpengaruh bagi masyarakat. Infotainment merubah nilai berita konflik menjadi informasi yang terkesan remeh temeh dan features yang menghibur. Hal tersebut menjadikan, bagaimana simbiosis konflik dalam hal ini kasus terorisme dikomodifikasi menjadi konten yang menaikkan rating media, tidak hanya dari sisi ketegangan yang dijual melalui berita tradisional tetapi juga dikemas menjadi sesuatu yang mengharu biru dan menghibur melalui infotainment. Segala informasi tersebut pada dasarnya merupakan informasi yang tak berpengaruh bagi publik. Namun, karena media mengekspose dari segala sisi, berita tersebut turut mempengaruhi kesadaran dan membuat pemirsa terus ingin tahu.
Dalam produksi infotainment, dapat diidentifikasi adanya standarisasi tertentu, mulai dari segmentasi audiens, format tayangan, pengemasan acara, ikon yang diangkat, gayapenyampaian, konten informasi yang dimuat, hingga jam dan durasi tayang. Hal ini bisa dilihat dari perkembangan infotainment yang awalnya ialah suatu rubrik hiburan kemudian menjadi tayangan informasi seputar selebritis. Penayangan program infotainment sebagai mainstream hiburan juga menjadikan artis atau selebritis sebagai tokoh utama yang 'dijual' kepada penonton. Dari segi produksi, hampir seluruh infotainment tidak menerapkan teknik jurnalisme yang rumit karena isinya hanya mengikuti kegiatan artis, meminta komentar artis dan mengkonfirmasi sebuah gosip tentang dirinya. Belakangan, muncul tayangan infotainment dengan format laporan investigasi seperti ditampilkan Silet (RCTI) dan Insert Investigasi (TransTV).

Namun, tetap saja kontennya tidak mengusung jurnalisme yang mendalam karena perluasan informasi hanya berkutat di orangorang sekitar artis atau satu-dua ahli yang turut berkomentar tentang isu yang mewarnai artis. Bahkan tidak jarang hanya berbekal satu atau dua pertanyaan. Selebihnya, penonton akan dibawa pada imajinasi dan pencitraan yang sudah melekat pada artis atau selebritis tersebut. Selebihnya, tayangan investigasi ini tetap lebih menjual rekaman gambar dan tampilan visual yang lebih didramatisasi melalui efek dan narasi yang bombastis.

\section{Kesimpulan}

Dari uraian di atas, dapat ditarik beberapa kesimpulan bahwa media memanfaatkan isu terorisme sebagai informasi yang memiliki daya jual tinggi. Hal tersebut ditunjukkan dari kemunculan berita mengenai kasus pengeboman yang terjadi di Sarinah Thamrin tidak hanya menjadi breaking news yang menyita waktu berjam-jam dalam pemberitaannya, melainkan kasus tersebut juga dapat dijual sebagai tayangan features yang berisi informasi ringan yang mengacaukan perhatian masyarakat dari isu yang menegangkan menjadi isu yang layak dikonsumsi setiap hari. Ketegangan tidak lagi menjadi sesuatu yang mengerikan dan mencekam bagi masyarakat dengan adanya komodifikasi konten yang disajikan melalui 
infotainment. Sehingga, beberapa poin penting yang di dapatkan adalah:

1. Terorisme bisa menjadi konten yang sangat menjual bagi media, terlebih dengan munculnya trend infotainment yang berasal dari tabloid dan diadopsi menjadi siaran program acara di televisi.

2. Infotainment bukan merupakan produk jurnalis, sehingga informasi yang disajikan mengenai teror bom Sarinah pun tidak memenuhi standar nilai berita yang ada.

3. Infotainment mendongkrak rating TV dengan menarik minat khalayak yang lebih tertarik dengan konten hiburan, sehingga masyarakat menjadi lebih tidak peka dan sejenak lupa terhadap kasus atau konflik itu sendiri.

\section{Reference}

Adam W Sukarno. 2011. Dilema Peliputan Terorisme dan Pergeseran Pola Framing Berita Terorisme di Media. Jurnal Ilmu Sosial dan Ilmu Politik

Albarran, B Alan. (1996). Media Economics, Understanding Markets, Industries, and Concept. Lowa State University Press. Lowa

Creeber, Glen (Ed). (2001). The Television Genre Book.London: British Film Institute.
Gordon, A. David dan John Michael Kitross. (1999). Controversies in Media Ethicn United States: Wesley Longman Educational Publishers Inc

Hartley, John. 2010. Communication, Cultural, \& Media Studies- Konsep Kunci. Yogyakarta:Jalasutra

Langer, J. 1998. Tabloid Television: Popular Journalism and The Other News. London: Routledge

Morris, Eric and Alan Hoe. 1987. Terrorism Threat and Response. London:Macmillan Press

Mosco, Vincent. (2009) . The Political Economy of Communication 2 Edition. Sage, London.

Nunung Prajarto. 2004. Terorisme dan Media Massa: Debat Keterlibatan Media. Jurnal Ilmu Sosial dan Ilmu Politik

Postman, Neil. (1985). Amusing Ourselves to Death: Public Discourse in the Age of Show Business. New York: Penguin Books

Rex A. Hudson dan Marilyn Majeska (ed), 1999, The Sciology and Phychology of Terrorism, Who Becomes a Terrorist and Why? Federal Research Division, Library of Congres, Washington, diakses melalui pada tanggal 13 Juni 2016 http://www.loc.gov/rr/frd/pdffiles/Soc_Psych_of_Terrorism.pdf, lih pada halaman 12 .

Stuart Cunningham. 2012. Emergent Innovation through the Coevolution of Informal and Formal Media Economies. SAGE

Unde, Andi Alimuddin. (2014). Televisi dan Masyarakat Pluralistik. Predana media Group: Jakarta 